\title{
The Importance of Teacher - Students Interaction in Communicative Language Teaching (CLT)
}

\author{
Moh. Abraham Akbar Eisenring ${ }^{1}$, Margana ${ }^{2}$ \\ ${ }^{1}$ Graduate School, Yogyakarta State University, Yogyakarta, Indonesia \\ ${ }^{2}$ Yogyakarta State University, Yogyakarta, Indonesia \\ Email: 1moh.abraham2016@student.uny.ac.id; 2margana@uny.ac.id
}

\begin{tabular}{l}
\hline Article Info \\
\hline Article history: \\
Submitted Dec 30, 2017 \\
Revised March 27, 2018; \\
Accepted April 11, 2018 \\
Published April 21, 2019
\end{tabular}

\section{Keywords:}

Communicative Language

Teaching,

English Language Teaching and Learning,

Interaction,

Learning Strategies,

Student-Centered Approach

\begin{abstract}
Interaction takes crucial part in English language teaching and learning. It could determine the successfulness of teaching and learning in the classroom. Relying on the fact, interaction becomes the main means for teacher and students to exchange their ideas, feelings, opinions, insights, and etc. Especially for the teachers themselves, maintaining interaction with students is considered to be very important thing. In this case, teachers need to employ some proper strategies and approaches in order to deal with such kind of activity. Nowadays, a great number of teachers apply student-centered approach more than teacher-centered one in the way they teach English. Student-centered approach is believed to be able to encourage the teachers to raise their awareness to interact more with the students by implementing Communicative Language Teaching (CLT). In this library-based research paper, the writers would like to elevate the importance of classroom interaction in Communicative Language Teaching (CLT) as an important means for teachers in their respective classrooms.
\end{abstract}

\section{Corresponding Author:}

Moh. Abraham Akbar Eisenring, Graduate School, Yogyakarta State University, Yogyakarta, Indonesia Karangmalang, Caturtunggal, Depok, Sleman, Yogyakarta 55281

Email: moh.abraham2016@student.uny.ac.id

\section{INTRODUCTION}

Interaction takes crucial part in English language teaching and learning. It could determine whether the learning objectives in each meeting in the classroom can be achieved or not. Relying on the fact, interaction becomes the main means for teacher and students to exchange their ideas, feelings, opinions, views, perceptions, and etc. Especially for the teachers themselves, maintaining interaction with students is very important. The approaches, methods, and techniques that the teacher applies in the classroom should be taken into account.

Communicative Language Teaching (CLT) is one of the teaching methods that is in line with student-centered approach. CLT sustains the students to be able to interact with the target language, by overwhelmingly promote communicative events to be learned in the classroom. Larsen-Freeman (2000) states that Communicative Language Teaching (CLT) makes communicative competence as the goal of language teaching and by acknowledging the interdependence of language and communication. Based on this point of view, it can be seen that language and communication are interdependent. Those two matters cannot be separated. It means that when students learn a new language, meaning that they must learn about how to communicate with that language or how to use the language properly. They are not just learning the theories, but 
should be emphasized more on practices. In applying CLT in the classroom, English teachers are required to be creative and active when they lead the classroom. In other words, the teachers should always try to find the way to make the class becomes interactive.

A lot of research was done regarding to classroom interaction. Shim (2007) identified the interaction patterns between teacher and students in the middle school classrooms in Seoul, Korea. Shim adapted Foreign Language Interaction Analysis (FLINT) system promoted by Moskowiz (1976) as the basis of analysis. The analysis showed that teacher talk is a lot more dominant than students' reaction. It was happening because teacher-fronted activities influenced the classroom. Moreover, Li, Shouhui, and Xinying (2011) introduced some methods in analyzing the classroom interaction, namely Flanders Interaction Analysis System (FIAS) and Social Network Analysis (SNA). Those methods are helpful for English teachers as they provide self-evaluation and selfimprovement for them.

Furthermore, Gorjian \& Habibi (2015) put an effort to promote conversation strategies to Iranian university students by having an experimental research. In this case, the authors focused on a strategy named turn-taking. Turn-taking refers to the process by which people in a conversation decide who is to speak next. Briefly, the main aim of this research was to enhance the learners' oral performance in doing turn-taking for an effective conversation in both formal and informal situations. The result of this study indicated that the group who got turn-taking instruction from the authors (the experimental group) outperformed the group who got traditional instruction. By recognizing this result, it can be declared that turn-taking instruction could develop learners' ability in interaction and oral communication significantly.

More recent studies about classroom interaction were implemented by Heikonen, Toom, Pyhalto, Pietarinen, and Soini (2017) and Farashaiyan \& Muthusamy (2017). Heikonen et al. (2017) investigated the primary strategies of classroom interaction utilized by student-teachers during their teaching practicum in Finland. According to the authors, the strategies that student-teachers employ in classroom interaction with students during teaching practice periods are surprisingly understudied. The result showed that the classroom interaction strategies used by studentteachers were categorized as cognitive strategies, behavioral strategies, and emotional strategies. Meanwhile, Farashaiyan \& Muthusamy (2017) conducted an experimental research to Malay ESL students by presenting some strategies of classroom interaction in order to develop their speaking performance. The authors utilized classroom interaction strategies such as questioning and negotiation of meaning which were implemented in the nature of cooperative learning. The findings of this study confirmed the previous findings done by a great number of scholars (Chillon, 2012; Ellis, 2004; Ling, 2003; Garcia, 2013; Mackey, 1998) which suggested that the use of interaction strategies could improve ESL students' speaking ability.

In this library-based research paper, the writers would like to elevate the importance of classroom interaction in Communicative Language Teaching (CLT). The writers expect that this article would enlarge the readers' comprehension (especially English teachers) about Communicative Language Teaching (CLT) and also generate their awareness about the importance of maintaining interaction with students when they make use of CLT as their teaching method.

\section{DISCUSSION}

\section{Communicative Language Teaching (CLT)}

Brown (2007) defines CLT as "an approach to language teaching methodology that emphasizes authenticity, interaction, student-centered learning, task-based activities, and communication for the real world, meaningful purposes". Moreover, Widdowson (1978) cited in Ohno (2006) sees the language learning in CLT is more than how to understand, speak, read, and write sentences, but how sentences are used to communicate. Language learning is not always concern with composing and comprehending correct sentences as isolated linguistic units of random occurrence, but also using sentences appropriately in order to achieve communicative purposes (Widdowson, 1978). In line with this idea, Madya (2013) suggests that the English teachers who apply CLT as their teaching method should invest the linguistic knowledge and the use of that knowledge in communication practice when guiding or helping the students in learning the language. 
As mentioned earlier, the goal of CLT is that the students could deal with the communicative competencies. Canale \& Swain (1980) argue that there are four competencies which are needed to be mastered by the students, namely: (1) grammatical competence; (2) sociolinguistic competence; (3) discourse competence; and (4) strategic competence. Grammatical competence refers to the ability to create grammatically correct utterances. Sociolinguistic competence indicates the ability to produce sociolinguistically appropriate utterances. Discourse competence concerns with the ability to produce coherent and cohesive utterances. The last one, which is strategic competence, deals with the ability to solve communication problems as they arise. If the students learn and apply those competencies nicely in the classroom, it can be said that they have successfully learned the target language and be able to communicate properly with the target language.

In terms of its characteristics, Brown (2007) proposes four interconnected characteristics of CLT, as follows.

1) Classroom goals focus on all of the components of communicative competence and not restricted to grammatical or linguistic competence.

2) Language techniques are designed to engage learners in the pragmatic, authentic, functional use of language for meaningful purposes. Organizational language forms are not the central focus, but rather aspects of language that enable the learner to accomplish those purposes.

3) Fluency and accuracy are seen as complementary principles underlying communicative techniques. At times, fluency may have to take on more importance than accuracy in order to keep learners meaningfully engaged in language use.

4) In the communicative classroom, students ultimately have to use the language, productively and receptively, in unrehearsed contexts.

In reference to the principles, Berns (1990, p. 104) as quoted by Savignon (2002) summarizes eight principles of CLT as follows.

1) Language teaching is based on a view of language as communication. That is, language is seen as a social tool that speakers use to make meaning; speakers communicate about something to someone for some purpose, either orally or in writing.

2) Diversity is recognized and accepted as part of language development and use in second language learners and users, as it is with first language users.

3) A learner's competence is considered in relative, not in absolute, terms.

4) More than one variety of language is recognized as a viable model for learning and teaching.

5) Culture is recognized as instrumental in shaping speakers' communicative competence, in both their first and subsequent languages.

6) No single methodology or fixed set of techniques is prescribed.

7) Language use is recognized as serving ideational, interpersonal, and textual functions and is related to the development of learners' competence in each.

8) It is essential that learners be engaged in doing things with language - that is, that they use language for a variety of purposes in all phases of learning.

(Berns, 1990, p. 104)

In the CLT classroom, the roles of both teacher and students are different. According to Larsen-Freeman (2000), the role of the teacher is to facilitate the communication in the classroom. In this role, one of his/her major responsibilities is to establish situations likely to promote communication. Besides that, the teacher also acts as an adviser, answering students' questions, and monitoring their performance. Students, on the other hand, are the communicators. Meaning that they are actively engaged in negotiating meaning - in trying to make themselves understood and in understanding others - even when their knowledge of the target language is incomplete. 
Because CLT employs student-centered approach, Larsen-Freeman (2000) mentions that the teacher's role is not too dominant. Students are seen as more responsible managers of their own learning. When applying CLT method in the classroom, the teacher should be aware that the students have their own characteristics. In other words, the students have their own feelings to find out in what situation they learn best. Regarding to this, Savignon (2002) declares that within classroom communities, as within society at large, some people are leaders and some prefer to be followers. Both are essential to the success of group activities. In this case, the teacher should be fair in forming groups for students. The teacher should recognize the characteristics of the students, whether they are the "leaders" or "followers". In order to reach fairness, the teacher may put those "leaders" and "followers" together in the same group, not put only all of the "leaders" in the same group and vice versa.

From the above explanations, it can be seen that the Communicative Language Teaching (CLT) method prioritizes the use of interaction in the process of teaching and learning. This is in line with the main goal of this method that makes the students to be able to cope with communicative competencies. The English teachers have an important role in this case. The way they lead the classroom and interact with students becomes the successful key for teaching and learning, especially in helping the students to reach all of the abilities contained in communicative competencies.

\section{Notions of Interaction}

When an EFL classroom is influenced by the Communicative Language Teaching (CLT) method, the interaction between teacher and students will happen frequently. The teacher and students approximately have the balance interaction in this case. Dagarin (2004, p. 128) argues that interaction as "a two-way process between the participants in the learning process". In other words, the teacher influences the learners and vice versa. Added to this, Brown $(2000$, p. 165) defines interaction as "the collaborative exchange of thoughts, feeling, or ideas between two or more people, resulting in a reciprocal effect on each other". Because it has a reciprocal effect on each other, the quality of interaction between teacher and students becomes crucial in determining the success of teaching and learning.

According to Long (1996) as cited in Muho \& Kurani (2011), interaction is the facilitator of language acquisition because it connects input (what learners hear and read); internal learner capacities, particularly selective attention; and output (what learners produce) in productive ways. It means that interaction provides learners with opportunities to receive comprehensible input and feedback as well as to make changes in their own linguistic output (Gass, 1997; Long, 1996; Pica, 1994; Swain 1995 quoted by Muho \& Kurani, 2011).

Ellis (1999, p. 1) proposes two different views related to the interaction in the second language acquisition. First, he views interaction as "the social behavior that occurs when one person communicates with another". He categorizes this kind of interaction as "interpersonal interaction". Interpersonal interaction is considered as the basic to human communication, as all communities, whether literate or not, engage in it. Interpersonal interaction can occur orally (by face-to-face interaction) or written (by reading a book, the interaction between writer and reader). Second, he claims that interaction is an activity that is happening in our minds. He names such kind of interaction as "intrapersonal interaction". Intrapersonal interaction specifically occurs in mental processing. For example, when we read a book, there is an interaction happens in our mind in order to be able to understand the content of that book. Other than that, when we are driving and seeing a traffic light, we consciously stop when the traffic light turns into red and then start to drive again when the traffic light turns into green. It is happening because there is an interaction within human minds that is resulted to an agreement between our minds and the actions we take. Ellis (1999) states that both interpersonal and intrapersonal interaction are closely connected with regard to both our use and our acquisition of language. Which is, intrapersonal interaction is required in order to interact interpersonally and, also, interpersonal interaction serves to trigger intrapersonal operations, including those that are involved in language acquisition. 
In reference to the compiled theories above, a great number of experts define the term 'interaction' in the similar veins. However, this present article adopts the definition stated by Brown (2000, p. 165) which asserts that interaction refers to the collaborative exchange of thoughts, feeling, or ideas between two or more people (in this case is the teacher and students), resulting in a reciprocal effect on each other. This notion is used as the operational definition of this library-based research paper in order to ease the readers in comprehending the significance of interaction.

\section{Types of Interaction}

In the previous section, Ellis (1999) provides two different types of interaction in general, namely interpersonal interaction and intrapersonal interaction. The former concerns with oral interaction and written interaction, meanwhile the latter deals with the interaction which is happening in our minds (mental processing). Considering that this paper is more focusing on the domain of English language teaching and learning, then in this case, the writers would like to elaborate some types of interaction which occurs in the classroom between the teacher and students.

Van Lier (1988) as cited in Papaja (2011) distinguishes four basic types of classroom interaction as presented below.

1) The teacher has no control over the topic and the activity;

2) The teacher controls the topic but not the activity;

3) The teacher controls the topic and activity;

4) The teacher controls the activity but not the topic;

Over the years, Van Lier (1991) in Papaja (2011) develops his framework about the types of interaction. He adds another aspect namely "the function of the language". The types of interaction concern with the function of language are:

1) Ideational (telling people facts, or experiences);

2) Interpersonal (working on relationships with people);

3) Textual (signaling connections and boundaries, clarifying, summarizing and revising);

Meanwhile, Abarca (2004) classifies three types of interaction in EFL classrooms, namely the teacher-dominated, teacher-centered, and student-centered classrooms. The teacherdominated classroom is the one where the teachers spend most of the time talking, and the students' participation is very limited. The teacher-centered classroom is the one where the teacher is controlling the students' participation through some classroom activities and students have the chance to participate. Finally, the student-centered classroom is the one where the students can participate more actively. It is quite easy to differentiate among them when we directly have an observation in the classroom. The approaches, methods, and techniques that the teacher applies in the classroom determine the kind of interaction that they have. In relation to the Communicative Language Teaching (CLT), the usual types of interaction which is occurred is student-centered.

In addition, Dagarin (2004) differentiates the types of interaction occurred in the classroom by the participants. It depends on who communicates with whom. The types of interaction can be seen as follows:

1) Teacher - Learners

2) Teacher - Learners / A Group of Learners

3) Learner - Learner

4) Learners - Learners 
The first form of interaction (teacher - learners) is established when a teacher talks to the whole students in the classroom. In this situation, the teacher has a role as classroom leader and decides what activity that the students will have at that time. The main function of this interaction is to practice particular language structure or vocabulary that they have learned. This kind of activity is named as "drill".

The second form of interaction (teacher - learners / a group of learners) is happening when the teacher refers to the whole students (similar to the previous type), but expects only certain students to answer his/her statement/question. The "certain" students here could be only one student or a group of students. This form of interaction is often used in checking the students' understanding about the lesson. In addition, this kind of interaction is also frequently used at the beginning of the lesson, specifically in guiding students into the lesson.

The third form of interaction (learner - learner) is conducted when the students get an assignment from the teacher and they are asked to do it in pairs. The role of the teacher in this kind of situation is as a mentor, watch the students' activity, walk around pairs and help them if necessary.

The last form of interaction (learners - learners) is happened when the students have a task to do in the form of groups. Let say that the activity in the classroom in this kind of interaction is the continuum of the previous section. After the students work in pairs, the teacher puts the pairs into a whole group and each pair reports on their work in front of the classroom. When each pair presents their work in the classroom to the whole students, the "learners-learners" interaction is happening.

Of those types of interaction, Dagarin (2004) states that the last two ways of organization are very useful in stimulating interaction among the students. A research conducted by Long et al. (1976) in Nunan (1991) shows that learners use considerably more language, and exploit a greater range of language functions when working in small groups as opposed to teacher-fronted tasks in which all students proceed in a lock-step fashion.

In reference to those provided types of interaction above, it be can realized that various kinds of interaction happens frequently in some communicative events, including teaching and learning process. Interaction between teacher and students is named as classroom interaction, which is used as the main means for them in exchanging their ideas, feelings, opinions, views, and perceptions while they are involved in teaching and learning process in the classroom.

\section{The Importance of Interaction in CLT}

As previously addressed, interaction takes crucial part in English language teaching and learning. It could determine whether the learning objectives in each meeting in the classroom can be achieved or not. Relying on the fact, interaction becomes the main means for teacher and students to exchange their ideas, feelings, opinions, views, perceptions, and etc. In this section, the writer would like to elaborate numerous opinions from the experts regarding to the emphasis of the importance of teacher - students interaction in CLT classroom.

Rahimpour \& Magsoudpour (2011) claim that teacher-students' and students-students' interactions play significant role in foreign language development. Interactions between teachers and students and also interactions among students will facilitate language development and will lead to better language learning. Added to this, Hall \& Walsh (2002) state that in language classrooms, interaction takes on an especially significant role in that it is both the medium through which learning is realized and an object of pedagogical attention. They add that through their interactions with each other, teachers and students construct a common body of knowledge. Besides that, they also serve mutual understandings of their roles and relationships, and the norms and expectations of their involvement as members in their classrooms. 
Furthermore, Allwright (1984) as quoted by Zhang (2009) regards interaction as the "fundamental fact of classroom pedagogy" because "everything happening in the classroom occurs through a process of live person-to-person interaction". During such kind of interaction, learners make efforts to generate comprehensible output, which turns to be sources of input for other interlocutors. In other words, interaction may help the learners got the great chance to express themselves as well as giving a chance to others to acquire some knowledge.

Moreover, Yanfen \& Yuqin (2010) state that the success of teaching depends to a large extent on the way teacher talk and interactions that occur between teachers and students. It means that the teachers should control the quantity of their talk in the classroom. They should balance the interaction with the students as good as possible, in other words, they should influence the classroom with student-centered approach.

Students - centered seems to need a communicative approach. Littlewood (1981) describes some of the contributions that communicative activities can make to language learning under four headings, as follows:

1) They provide 'whole-task practice'

Teague et al. (1994) declare that whole-task practice consists of presenting a complete task to learners so that they are able to practice the task a single unit. Whole-task practice can be said as "experiential approach". Thus, the students learn speaking by speaking, reading by reading, and the like. In foreign language learning, whole-task practice is conducted through various kinds of communicative activity, structured in order to suit the learners' level of ability.

2) They improve motivation

The learners' ultimate objective is to take part in communication with others. Their motivation to learn is more likely to be sustained if they can see how their classroom learning is related to this objective and helps them to achieve it with increasing success.

3) They allow natural learning

In fact, many aspects of language learning can take place only through natural processes, which operate when a person is involved in using the language for communication. If this is so, communicative activity (inside or outside the classroom) is an important part of the total learning process.

4) They can create a context which supports learning

Communicative activity provides opportunities for positive personal relationships to develop among learners and between learners and teacher. These relationships can stimulate a good situation in the classroom and to create an environment that supports the individual in his efforts to learn.

From the above discussions, it can be recognized that interaction seems to have an important role in English language teaching and learning, particularly in CLT method. It apparently becomes the main means for teacher and students to exchange their ideas, feelings, opinions, insights, and etc. Besides, interaction serves benefits to all of the parties in the classroom, including the teacher and the students, as it can be fruitful for them in achieving their teaching and learning objectives in the classroom. 


\section{CONCLUSION}

When applying Communicative Language Teaching (CLT) method in the classroom, interaction should be taken into account among the English teachers as it takes a crucial part in determining the successfulness of teaching and learning. All of language acquisition in the classroom is done because there is an interaction between the teacher and the students. As previously expressed, interaction becomes the main means for the teacher and students to exchange their ideas, feelings, opinions, insights, and etc. Because the CLT method adopts a student-centered approach, maintaining good interaction with students becomes the key task for the English teacher in order to make students are able to achieve the communicative competencies.

With regard to the importance of interaction, the writers strongly suggest that the English teachers to maintain interaction with the students as good as possible. In this case, the English teachers are required to be creative and active when they lead the classroom. It means that they should always try to find the way to make the class becomes interactive. Teaching creatively and actively will facilitate students to have the opportunity to learn in a meaningful way, particularly in learning English through the use of CLT method.

\section{ACKNOWLEDGEMENT}

The writers would like to express their gratitude to all academicians in Yogyakarta State University for their kindness, support and motivation during the process of article writing.

\section{DAFTAR PUSTAKA}

Abarca, M. F. (2004). Interaction in the English classroom; An exploratory study. Revista Electronica "Actualidades Investigativas en Educacion, 4 (1), 1-24.

Brown, H. D. (2000). Teaching by principles: An interactive approach to language pedagogy (2nd ed.). New York: Longman.

Brown, H. D. (2007). Principles of language learning and teaching (5th ed.). New York: Pearson Education, Inc.

Canale, M. \& Swain, M. (1980). Theoretical bases of communicative approaches to second language teaching and testing. Applied Linguistics, 1 (1), 1-47.

Dagarin, M. (2004). Classroom interaction and communication strategies in learning English as a foreign language. English Language and Literature Teaching, 1 (2), 127-139.

Ellis, R. (1999). Learning a second language through interaction. Amsterdam: John Benjamins Publishing Co.

Farashaiyan, A. \& Muthusamy, P. (2017). The impact of classroom interaction strategies on Malay ESL students' speaking performance. Journal of Advance in Social Science and Humanities, 2 (12), 20239-20246.

Gorjian, B. \& Habibi, P. (2015). The effect of conversation strategies on the classroom interaction: The case of turn taking. Journal of Applied Linguistics and Language Learning, 1 (1), 14-23.

Hall, J. K. \& Walsh, M. (2002). Teacher-student interaction and language learning. Annual Review of Applied Linguistics, 22, 186-203.

Heikonen, L., Toom, A., Pyhalto, K., Pietarinen, J., \& Soini, T. (2017). Student-teachers' strategies in classroom interaction in the context of the teaching practicum. Journal of Education for Teaching, 1-16. 
Larsen-Freeman, D. (2000). Techniques and principles in language teaching (2nd ed.). New York: Oxford University Press.

Li, L., Shouhui, Z., \& Xinying, C. (2011). Beyond research: Classroom interaction analysis techniques for classroom teachers. $4^{\text {th }}$ Redesigning Pedagogy International Conference, Singapore.

Littlewood, W. (1981). Communicative language teaching: An introduction. New York: Cambridge University Press.

Madya, S. (2013). Metodologi pengajaran bahasa: dari era prametode sampai era pascametode (1 ${ }^{\text {st }}$ ed.). Yogyakarta: UNY Press.

Moskowiz, G. (1976). The classroom interaction of outstanding foreign language teachers. Foreign Language Annals, 9, 125-157.

Muho, A. \& Kurani, A. (2011). The role of interaction in second language acquisition. European Scientific Journal (ESJ), 16, 44-54.

Nunan, D. (1991). Language teaching methodology: A textbook for teachers. New York: Prentice Hall International English Language Teaching.

Ohno, A. (2006). Communicative competence and communicative language teaching. International Publication of the Bunkyo Gakuin University, 25-31.

Papaja, K. (2011). Analyzing types of classroom interaction in CLIL. Glottodidactica XXXVIII, 38, 4352.

Rahimpour, M. \& Magsoudpour, M. (2011). Teacher-students' interactions in task-based vs formfocused instruction. World Journal of Education, 1 (1), 171-178.

Savignon, S. J. (2002). Interpreting communicative language teaching: Contexts and concerns in teacher education. London: Yale University Press.

Shim, J. (2007). Teacher talk as strategies in the classroom. The Research Institute of Korean Education, 73-88.

Teague, R. C., Gittelman, S. S., \& Park, O. (1994). A review of the literature on part-task and wholetask training and context dependency. Virginia: U.S. Army Research Institute for the Behavioral and Social Sciences.

Widdowson, H. G. (1978). Teaching language as communication. Oxford: Oxford University Press.

Yanfen, L. \& Yuqin, Z. (2010). A study of teacher talk in interactions in English classes. Chinese Journal of Applied Linguistics, 33 (2), 76-86.

Zhang, S. (2009). The role of input, interaction and output in the development of oral fluency. English Language Teaching, 2 (4), 91-100. 